Energy Research Journal 1 (2): 51-54, 2010

ISSN 1949-0151

(C) 2010 Science Publications

\title{
Managerial Administration of Farming Machinery for Rice Production
}

\author{
Yosphatrachai Phuangpee and Pradtana Yossuck \\ School of Administrative Studies, Maejo University, Chiang Mai 50290
}

\begin{abstract}
Problem statement: This research was conducted due to an increase of agricultural machinery cost for rice production $(46.00 \%)$ of farmers in Phichit province. Based on an analysis of cost reduction using the method of John Deere, it was found that this may decrease from 46.00-28.50\% of the total cost. Thus, there was a question how to mange the agricultural machinery. The objective of this research was to investigate the pattern of managerial administration of farming machinery for rice production, Phichit province. Approach: Research methodology in this research had many steps: Indepth interview with rice farmer members and farmer institution executives having good practice; an analysis of internal and external factors concerning about the managerial administration of rice farmer group; public hearing forum of stakeholders on rice farmer group management and the investigation of decision-making on the selection of management strategies. Descriptive statistics and Pearson coefficient relation were used in this research. Results: Findings showed that there were four models of the managerial administration of agricultural machinery as follows: External hiring, co-investment, networking and participatory maintenance. For the management of farmer group, it should be in the form of networking connecting each sub-group. Also, it should have a coordination center for the planning of agricultural machinery, capital and welfare management. The management was dependent on three groups of strategies: (1) strategy a-the improvement of the managerial administration structure and grouping concept base; (2) strategy b-the development of potential and quality of the managerial administration and (3) strategy c-the creation of atmosphere in the participatory managerial administration of agricultural machinery, respectively. Conclusion: The implementation based on this model caused the farmers have confidence, unity and systematic working and power on the persuasions for group activity participation more than ever.
\end{abstract}

Key words: Management, farming machinery, rice production

\section{INTRODUCTION}

At present, rice production cost of farmers in Phichit province is increased due to the use of agricultural machinery in place of workforce. Based on the method of Deere (1992); Intharasanti and Satjawewan (2008) assessment of energy expenses on agricultural machinery in cropping year 2007-2008, it was found that the energy expenses comprised water pumping, soil preparing, harvesting, threshing, rice seed transporting and yield selling which was 46 percent of the total expenses. This was considered to be higher than other expenses on rice production. Besides, there is a high price of fuel oil and agricultural machinery at present. Not only this, each rice farmer prefers to buy their own agricultural machinery causing accumulated debts. They don't mind the model of joint machinery ownership for the reduction of rice production cost (Edwards, 2001). This problem led to the objective of this research which sought to find pattern of managerial administration of farming machinery for rice production in Phichit province. Specially, the objectives of this research aimed to investigate the following: (1) agricultural machinery cost for rice production; (2) factors related to the managerial administration of agricultural machinery and (3) the model construction and development of the managerial model construction and development of the managerial administration of agricultural machinery leading to the development of the energy reduction method of the agricultural machinery for rice production of the farmers.

\section{MATERIALS AND METHODS}

This descriptive research was conducted from April, 2007 to December 2008 using various forms of data collection. This began with structured-interview with a group of 376 rice farmers concerning about the

Corresponding Author: Yosphatrachai Phuangpee, School of Administrative Studies, Maejo University, Chiang Mai 50290 Tel: 08-7199-5511, Tel/Fax: 0-5541-6038 
expenses on agricultural machinery for rice production and need for agricultural machinery. In-dept interview was also conducted with 27 farmer group executives in Phichit province and 33 members of agriculture institution both inside and outside Phichit province concerning about the existing managerial administration of agricultural machinery and factors related to the managerial administration of agricultural machinery. Also, there was an analysis of internal and external factors concerning about the managerial administration of the rice farmer group using the 7 internal factors analysis of McKinsey (McKinsey 7-s frameworks) comprising system, structure, strategies, staff, skills, style and co-value. For external factors analysis, it was dependent on the PEST+ELI analysis comprising public policy and politics, economy, society, technology, environment, law and industry. Data synthesis was also mutually conducted to construct a model of the managerial administration of agricultural machinery and to determine the formulation of the managerial administration of agricultural machinery strategies. The feasibility of the formulation was also monitored by holding public hearing forum of 46 stakeholders on the managerial administration of the rice farmer group. Lastly, investigated decision-making on the selection of strategies group applied in the actual situation in Phichit province using structured-interview with 43 stakeholders. Descriptive statistics and Pearson co-efficient relation were used in this research.

\section{RESULTS}

The model of the managerial administration of agricultural machinery for the reduction of rice production cost of farmers in Phichit province as it should be consisted of the following: Form of external hiring; co-investment; networking and participatory maintenance; monitoring of the feasibility of the formulation of model and strategies by holding public hearing forum of 46 stakeholders. There was the coordination center for agricultural machinery service and planning of farmer and managerial administration of rice farmer group, agricultural machinery, capital and welfare.

The structure of management administration as it should be consisted of two the following (1) strategic section-responsible for the whole managerial administration of the rice farmer group e.g., determination of the goal, policy, organization strategies, executive qualification and personnel, approval, control, monitoring, financial system, accounting, wage, salary, communication system, machinery and tool allocation and the determination of various services and (2) main operation section-this response to the main objectives of the rice farmer group. This managerial administration was divided into two parts (a) secretary section responsible for finance, accounting, wage, salary, share as well as coordination with internal and external networks for the information connection with various agencies and (b) development and maintenance of agricultural machinery sectionresponsible for research and development as well as maintenance and agricultural machinery service. This part may have a staff of various networks or it may ask for a staff of government or private agencies to handle the task of this part

With regards to capital and welfare aspects, rice farmer members should get benefits from the group rather than from an individual. However, partnership organization should be adopted since there was benefit sharing (after cost subtraction) to all share holders. Besides, it was a system which the community was familiar with it through grouping of rice farmers such as village fund group, Sat-ja group, enterprise fund system, village cooperative system, welfare fund system and capital flow system. Besides, benefits sharing of the rice farmer group should be considered on net returns which all kinds of members obtain such as the committee of the managerial administration of agricultural machinery, all levels of service staff, agricultural machinery owners and provision and hiring of agricultural machinery representatives (middlemen as called by rice farmers). The benefit obtained should be in the forms of daily, monthly and yearly matters depending on the kind of benefits. However, the obtained benefits should be equal to the returns (gross profit) $(100 \%)$ as the rice farmers had agreed to the regulations of the rice farmer group. This was subtracted by the different efficiency outcome value as a whole of the agricultural machinery and equipment (OEE) (\%) before (100\%) and after using the agricultural machinery $(\%)$ as the computation formula shown below:

Net returns $(\%)=\begin{aligned} & \text { Gross profit } \\ & \text { equipment effectiveness }(\%)\end{aligned}$

The managerial administration strategy of agricultural machinery and its application to the actual area of Phichit province should consist of three main strategic groups: (1) strategy a-it goal was to adjust the structure and system of the managerial administration as well as the adjustment of the concept basic of rice farmer grouping. This was aimed to increase the efficiency and effectiveness of the managerial administration of agricultural machinery. This was 
included in the mission of the mutual planning on the managerial administration of agricultural machinery. The main factor which must be taken into consideration was transparency in the managerial administration; (2) strategy b-it was aimed to develop potential and quality of the strategic managerial administration of agricultural machinery. It also had the mission on good flow capital system management with transparency and ethics as well as an increase of agricultural machinery numbers. The main factors which must be considered were the enrichment of knowledge and rice farmer grouping supporters and (3) strategy c-this was aimed to create the atmosphere of participatory managerial administration, good implementation report and the integration of knowledge transfer among networks. Besides, various concerned data base and new leaders were established. Its main mission was to evaluate and report outcome of the implementation. There was also the provision of various activities to promote and support grouping of rice farmers, creation of new leaders and data base. However, the main factor to be considered was the diversified of increased welfare.

The effective application of the managerial administration strategy of agricultural machinery must assess the capability and needs of rice farmers, community, organizations and concerned personnel of all levels. This must begin with the implementation based on the strategies (a), (b) and (c), respectively for the confidence and unity of rice farmers. Moreover, they must work systematically and be willing to help each other for the creation of persuasion power to join group activities. Based on an analysis of importance weighting among the three strategy groups using the Analysis Hierarchy Process; AHP, it was found that the three strategy groups passed a level of reliability (total consistency ratio; 0.068 ). The highest level of reliability fell into the strategy (a) (total weighted evaluations; 0.552 ), followed by strategy (b) (total weighted evaluations; 0.295) and strategy (c) (total weighted evaluations; 0.154), respectively. The criterion for the consideration of the strategy selection leading to the implementation of the strategy (a) must place the importance of expense weight most (factor weights; $0.556)$. This was followed by the possibility criterion (factor weights; 0.552) and the criterion of sustainability (factor weights; 0.537), respectively. For strategy (b) the weight on the criterion of sustainability was ranked the highest (factor weights; 0.311). This was followed by the criterion of resources (factor weights; 0.295) and the possibility (factor weights; 0.289 ), respectively. For strategy (c) the weight on the criterion of the possibility was ranked the highest (factor weights; 0.160), followed by the criterion of sustainability (factor weights; 0.157) and expenses (factor weights; 0.149), respectively.

\section{DISCUSSION}

The analysis and synthesis of the model and strategies of the managerial administration of agricultural machinery was done by the researcher as the outsider in which it might not conform to needs of the rice farmers as it should be. However, there was conformity of outcomes of the public hearing forum of the stakeholders and results of the analysis and synthesis. That was the two parties agreed that the development rice farmer group should be conducted step by step. This begins with the management of agricultural machinery which is dependent on external hiring. Later on, construct the strength of the rice farmer group until they are able to manage the group by themselves. In fact, the data used in the analysis and synthesis of the researcher were truly obtained from the farmer target group. Besides, there are results of the studies of researchers reveal that the consideration and recommendations on strategies should conform to theory principles, policy and goal of concerned agencies. Results of this study conformed to a study of Intharasanti and Satjawewan (2008) that the analysis of form and guidelines for the development of the managerial administration system in accordance with the conceptual framework of McKinsey 7-S model and PESTE-E qualitative analysis and results of the analysis on the possibility on practice using SWOT quantitative analysis conformed to each other. This makes a high possibility in guidelines for the development of the managerial administration system.

\section{CONCLUSION}

It is advisable that a good and sustainable development of the rice farmer group should be dependent on cooperation among various concerned personnel and agencies. Also, they must sacrifice and place the importance of mutual benefits under the concept of the mutual managerial administration of resources. This must keep in mind on the three parts of relationships: (1) rice farmer group management; (2) capital management and (3) the management of agricultural machinery. These three parts can be evaluated based on the consideration of the formula obtained from results of this study-net returns $=$ gross profit $(100 \%)$ as agreed by the rice farmer group and subtracted by the different of total efficiency values of the machinery and equipment (OEE) (\%) before and after using. 


\section{ACKNOWLEDGEMENT}

The researchers would like to thank the Commission on Higher Education, Thailand and Uttaradit Rajabhat University for supporting a grant under the program "Strategic Scholarships for Frontier Research Network for the Ph.D. Program Thai Doctoral degree" for this research.

\section{REFERENCES}

Deere, J., 1992. Machinery Management. Deere and Company Service Publication, ISBN: 0-86691170-7, pp: 58-68.
Edwards, W., 2001. Join machinery ownership. http://www.extension.iastate.edu/Publications/PM1 373.pdf

Intharasanti, W. and A. Satjawewan, 2008. An analysis of model and guidelines for the system development of the managerial administration of nursing services of Baan pong. Nurs. Educ. 2: 19-21. 